\title{
Determination of Lower and Middle Linear Saturated Fatty Acids in Water
}

\author{
Keizo OGInO, Kazuhiko AiBARA, and Masanori FujIYAMA \\ Faculty of Science and Technology, Science University of Tokyo \\ (Noda, Chiba)
}

\begin{abstract}
The conductivities of dilute aqueous solutions of lower and middle linear saturated fatty acids were determined at $25^{\circ} \mathrm{C}$. The characteristic relationships between conductivity and concentration of solutions of the fatty acids were obtained for each carbon number of the acid, respectively. The experimental equation to present conductivity of a solution as a function of total ionic molar concentration of fatty acids is given by

$$
K=0.375 \times C+2.0 \times 10^{-6}
$$

where $K$ is conductivity (mho/cm), and $C$ is total ionic molar concentration (M) of fatty acid. These relationships and the equation would serve to calibrate the amount of fatty acids in water from conduc= tivity measurement when fatty acids are the predominant components in water and the measurement of conductivity is not interfered with the other ions.
\end{abstract}

\section{Introduction}

Water-soluble oily materials are public water pollutants and their determination is current need to estimate and to prevent the pollution.

A few methods have been proposed for the determination of fatty acids such as $\mathrm{GLC}^{13,2)}$, liquid chromatography with a thermal detector ${ }^{32}$ and the monomolecular film equilibrium-lens method $^{4}$, but they are not so conventional as to be fitted to the field surveys.

In this study, the conductivities of fatty acids in water were measured in relation with the carbon number and the concentration of the acids. The results were comprehensible on the basis of the dissociation properties of the acids and the applicability of the relations to the determination of trace amounts of fatty acids in water was discussed.

\section{Experimental}

Materials Water used in this experiment was of conductivity about $2.0 \times 10^{-6} \mathrm{mho} / \mathrm{cm}$. Fatty acids were acetic acid $\left(\mathrm{C}_{2}\right)$ from Wako Pure Chemical Industries Ltd., propionic acid $\left(\mathrm{C}_{3}\right)$, butyric acid $\left(\mathrm{C}_{4}\right)$, Valeric acid $\left(\mathrm{C}_{5}\right)$, hexa= noic $\left(\mathrm{C}_{6}\right)$, heptanoic acid $\left(\mathrm{C}_{7}\right)$, octanoic acid $\left(\mathrm{C}_{8}\right)$, and nonanoic acid $\left(\mathrm{C}_{9}\right)$ from Tokyo Kasei Kogyo Co. Ltd. These fatty acids were specified to have 98 99\% purity by GLC.

Apparatus Conductivities of the solutions were measured with a Conduct Meter Model $\mathrm{CM}-5 \mathrm{~B}$, and $\mathrm{pH}$ was measured with a $\mathrm{pH}$ Metes Model HM-5A, both of Toa Electric Wave Co. $\mathrm{Ltd}$. at $25^{\circ} \mathrm{C}$.

\section{Results and Discussion}

The conductivities of the fatty acid solutions are plotted against the concentration in ppm of the acids in Fig. -1 and 2. The solubilities of the fatty acids in water become smaller with increasing carbon number, and consequently th $\epsilon$

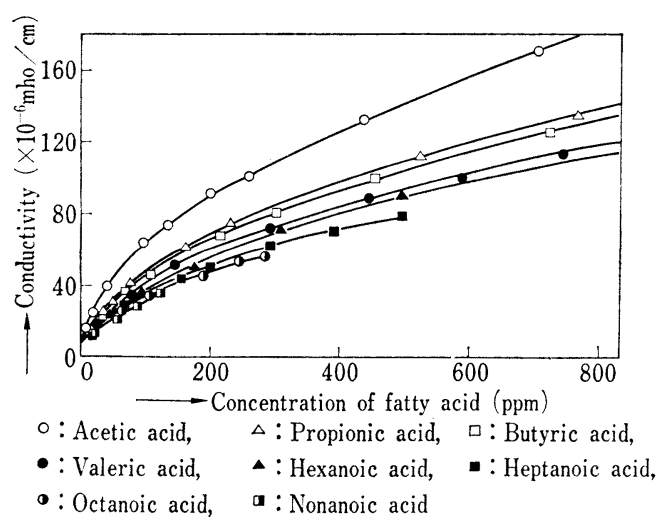

Fig.-1 The relationship between the conductivity and concentration of fatty acid in ppm. 


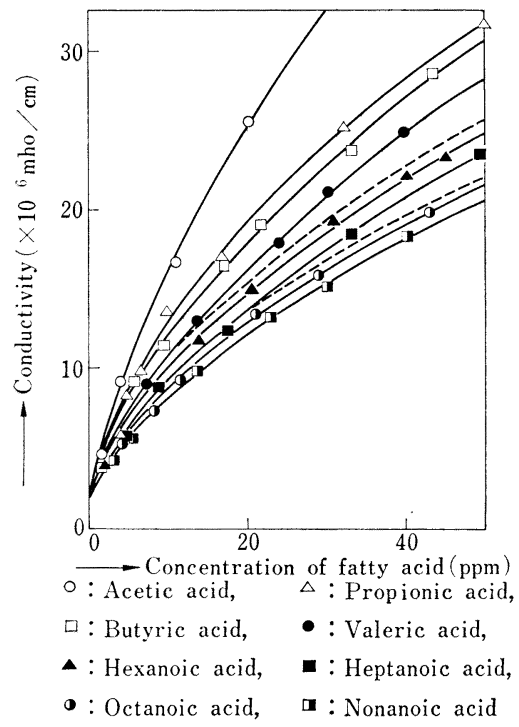

Fig.-2 The relationship between the conductivity and concentration of fatty acid in ppm.

conductivity measurements for the acids of $\mathrm{C}_{7}$, $\mathrm{C}_{8}$ and $\mathrm{C}_{9}$ were performed in concentration ranges below about $500 \mathrm{ppm}$ of heptanoic acid, about $280 \mathrm{ppm}$ of octanoic acid and about 120 ppm of nonanoic acid. These solubilities of the fatty acide were considerably smaller than those reported by the literature ${ }^{5)}$. Fig. -2 shows the relationships between the conductivities and the concentrations of the solutions presented in Fig. -1 in an expanded scale. These relas tions show that the conductivity of the solution increases with the increase of the concentration of the acid in the solution. The results suggest that these linear curves can be applied to the determination of trace amount of fatty acids in water as calibration curves if the water contains the single contaminant.

When the concentrations of the fatty acids were kept constant, the conductivities of the solutions change in a decreasing tendency along with the increasing carbon number of the acids as shown in Fig. -3, Thus, the conductivity of a fatty acid solution is a function of both of concentration and carbon number of the fatty acid, i.e. linearly increasing with increasing concentration and decreasing with increasing carbon number of the acid.

The conductivities of the solutions are pre= sented in relation with the molar concentration (M) in Fig. -4 in which the two characteristic

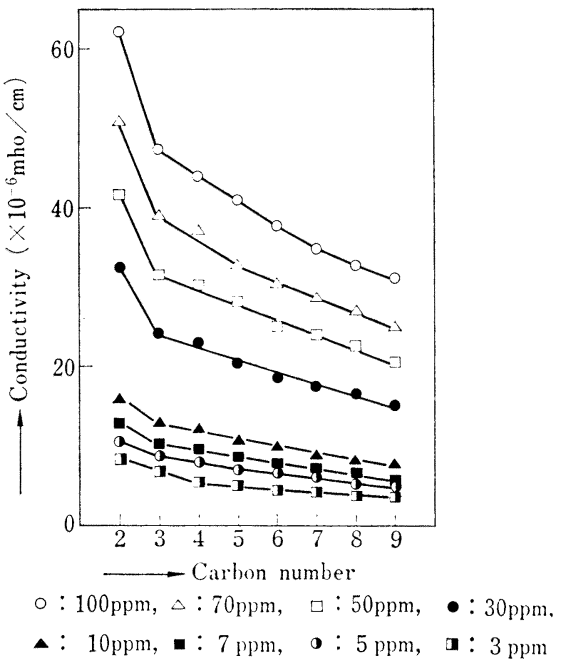

Fig.-3 The relationship between conductivity and carbon number of fatty acids at certain concentrations.

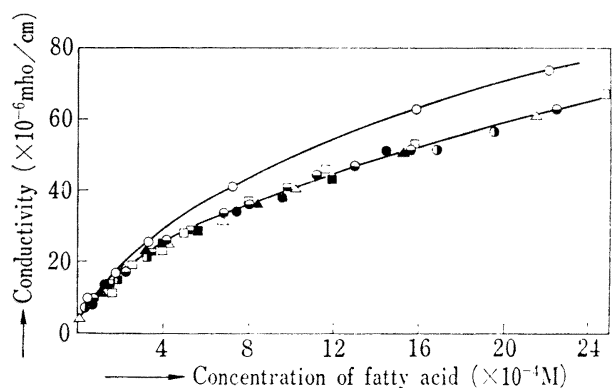

$\circ$ : Acetic acid, $\triangle$ :Propionic acid, $\square:$ Butyric acid.

$\bullet$ : Valeric acid, $\Delta$ : Hexanoic acid, - : Heptanoic acid,

- : Octanoic acid, $\mathbf{x}:$ Nonanoic acid, $\bullet:$ Mlixed fatty acid $5 \mathrm{~A}$,

$\because$ : Mixed fatty acid $7 \mathrm{~A}$

Fig. -4 The relationship between the conductivity and concentration of fatty acid in mole.

Table-1 Dissociation constant $\left(25^{\circ} \mathrm{C}\right)$.

\begin{tabular}{l|c|c}
\hline Acids & Obs. & Ref. \\
\hline $\mathrm{C}_{2}$ & $1.91 \times 10^{-5}$ & $1.753 \times 10^{-5}$ \\
$\mathrm{C}_{3}$ & $1.38 \times 10^{-5}$ & $1.336 \times 10^{-5}$ \\
$\mathrm{C}_{4}$ & $1.50 \times 10^{-5}$ & $1.513 \times 10^{-5}$ \\
$\mathrm{C}_{5}$ & $1.44 \times 10^{-5}$ & $1.380 \times 10^{-5}$ \\
$\mathrm{C}_{6}$ & $1.36 \times 10^{-5}$ & $1.389 \times 10^{-5}$ \\
$\mathrm{C}_{7}$ & $1.33 \times 10^{-5}$ & $1.279 \times 10^{-5}$ \\
$\mathrm{C}_{8}$ & $1.26 \times 10^{-5}$ & $1.276 \times 10^{-5}$ \\
$\mathrm{C}_{9}$ & $8.32 \times 10^{-6}$ & $1.109 \times 10^{-5}$ \\
\hline
\end{tabular}

curves for acetic acid and for the acids with the carbon numbers from $\mathrm{C}_{3}$ to $\mathrm{C}_{9}$ were separately obtained. The splitted curves would be attribs 
uted to the difference of dissociation constant of acetic acid from those of the higher acids which are presented in Table-1.

The values of dissociation constants given in Table- 1 were determined by the $\mathrm{pH}$ measure $=$ ments of the fatty acid solutions. The observed values for even carbon number fatty acids except acetic acid approximately coincided with those reported by the literature ${ }^{6}$, , but those for odd carbon number fatty acids were somewhat differ= ent from the referred values ${ }^{6}$. Because of the low solubility and little dissociation constant of nonanoic acid in water, the observation tends to include larger error and it would be the main reason of the discrepancy in the result of this study and the previously reported one ${ }^{6}$.

The dependency of the conductivity of fatty acid solutions on the ionic molar concentrations was presented in Fig.-5. The ionic molar

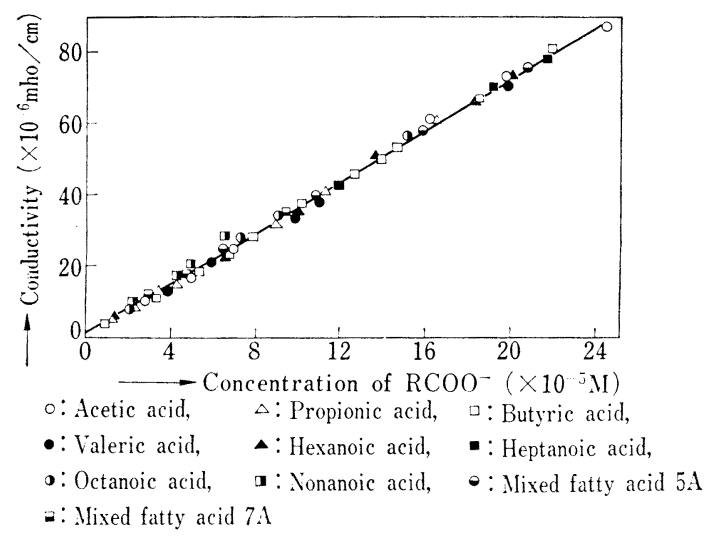

Fig. - 5 The relationship between the conductivity and concentration of $\mathrm{RCOO}^{-}$

concentrations were derived from the molar con= centrations and the dissociation constants. A straight relationship was obtained for all exam = ined members of fatty acids, without the influence of carbon number of the acids. An experimental equation relating the conductivity and the ionic molar concentration in the solution was derived from the result.

$$
K=0.375 \times C+2.0 \times 10^{-6}
$$

where $K$ is conductivity (mho/cm) and $C$ is ionic molar concentraion (M). Using this eque ation, the total ionic concentration of the fatty acids is determined from the conductivity of the solution.
Table-2 Composition of mixed fatty acid.

\begin{tabular}{l|r|r}
\hline Acids & $5 \mathrm{~A}$ & $7 \mathrm{~A}$ \\
\hline $\mathrm{C}_{4}$ & 3 & - \\
$\mathrm{C}_{5}$ & 24 & - \\
$\mathrm{C}_{6}$ & 53 & 5 \\
$\mathrm{C}_{7}$ & 11 & 22 \\
$\mathrm{C}_{8}$ & 5 & 27 \\
$\mathrm{C}_{9}$ & 3 & 31 \\
$\mathrm{C}_{19}$ & 1 & 14 \\
\hline
\end{tabular}

Next, the specimen solutions of mixed fatty acids were submitted to conductivity measure= ments. The solution $5 \mathrm{~A}$ contains pentanoic acid and heptanoic acid as main components and the solution 7A mainly contains heptanoic acid, octanoic acid and nonanoic acid. The total fatty acid concentrations in the solutions $5 \mathrm{~A}$ and $7 \mathrm{~A}$ were varied in the range below 20 $\times 10^{-5} \mathrm{M}$ in total ionic molar concentration, but the concentration ratios of the components with each other were kept constant respectively. The conductivities of the mixed fatty acids are shown in Fig-2 in relation with the concen= trations of the total acids in ppm by dotted lines. The line for $5 \mathrm{~A}$ is sited between the lines for pentanoic and hexanoic acids, and the line for 7A between the lines for heptanoic and octanoic acids. In Fig. -4 , the conductivities of the solutions of mixed acids were presented in relation with the molar concentrations which were determined from mean molecular weights of the mixed acids. The plots were on the same line with those for the solutions of single fatty acid from $\mathrm{C}_{3}$ to $\mathrm{C}_{9}$.

These observations suggest that the concent= ration of soluble fatty acids in water can be determined by the measurement of conductivity in the concentration range up to a few hundred ppm, irrespective of the carbon number of the acids and the states of mixing.

(Received June 22, 1978)

\section{References}

1) K. Konishi and Y. Kanō, Japan Analyst, 13, 299 (1964).

2) K. Fukui, H. Nagatomi, and S. Murata, Bunseki Kagaku, 11, 432 (1962).

3) K. Horikawa, Japan Analy'st, 21, 808 (1972).

4) S. Kobayashi and K. Yamauchi, Kasei Gaku Zasshi, 27, 134 (1976).

5) Yukagaku Kyokai (ed.), "Yushi Kagaku Beno 
ran", Maruzen (1958) p. 207.

6) Nippon kagaku kai (ed.), "Kagaku Benran (Kiso II)”, Maruzen (1966) p. 1055.

水中の低・中級直鎖飽和脂肪酸の定量

荻野圭三，粟飯原和彦，藤山雅規 東京理科大学理工学部工業化学科

（千葉県野田市山崎 2641）
低・中級直鎖飽和脂肪酸の希薄水溶液の電導度を $25^{\circ} \mathrm{C}$ で測 定した。脂肪酸の電導度已浱度の間には, 各脂肪酸について特 徵ある曲線が得られた。この結果から, 各曲線は, 脂肪酸を定 量するために検量線として用いることができると考えられる。 イオンモル濃度に対する電尊度の実験式が次のように得られ た。

$$
K=0.375 \times C+2.0 \times 10^{-6}
$$

ここで $K$ は電導度 $(\mathrm{mho} / \mathrm{cm})$, そして $C$ はイオンモル濃度 (M)である。 